\title{
ERNEST B. ELDRIDGE
}

By the death of Ernest Eldridge on the I4th February I966 at the age of 8I years, ASTIN has lost one of its earliest members and, in fact, one of the small band of enthusiasts who worked hard to bring together actuaries throughout the world who were interested in non-life insurance.

$\mathrm{He}$ qualified as an Associate of the Institute of Actuaries in I907, but his interests were with non-life rather than life insurance and after having held various appointments, including that of Accident Manager of the Eagle Star, he set up the insurance brokerage firm of Eldridge \& Co., specialising in excess of loss reinsurances.

He did not take a very active part in the discussions at the Institute of Actuaries but will be remembered amongst early ASTIN members because of the part he played in the special meetings organised during the Congress in Scheveningen in I95I. In addition to suggesting to the Dutch hosts that the subject of Excess of Loss Reinsurance was a suitable special subject, he presented one of the four papers which were discussed at the meeting. Those concerned will remember the problem presented to our hosts as the numbers of intending participants grew from a mere handful to more than 70 during the first few days of the Congress. This support gave the first real indication of the extent of the potential interest in forming an association on non-life actuaries:

He was well known in the City of London insurance market and the-annual cocktail parties he arranged were unique at the time in providing a forum for all sides of the industry to discuss their common problems.

From a personal point of view I am conscious of the loss of a good friend and wise counsellor. It was through him that I first met Paul Johansen in the late I940's and we discussed the possibility of international co-operation in the non-life field and this, as far as I am concerned, was the first positive step in my ASTIN history.

His loss will be sadly felt and we extend to Mrs. Eldridge, who so many of us have been charmed to meet on various occasions, our sincerest condolences.

London, the 25th of March $1966 \quad$ R. E. BEARD 